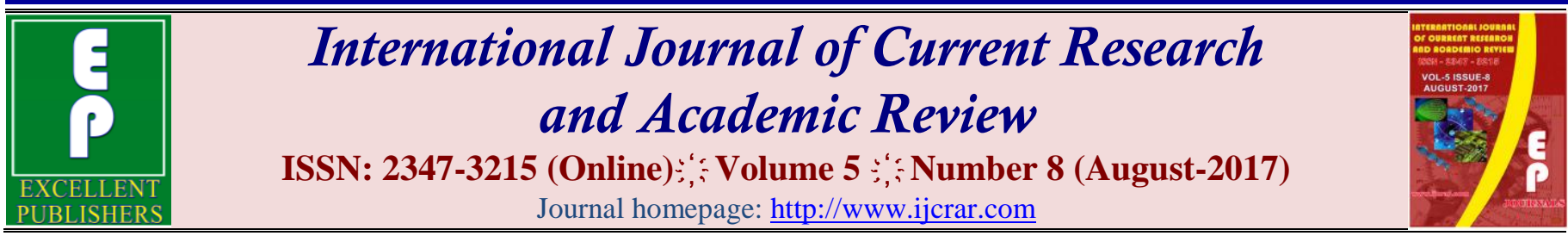

doi: https://doi.org/10.20546/ijcrar.2017.508.010

\title{
Evaluation of Soil Health under Different Forest Stands in a Tropical Moist Rain Forest of Otuoke, Southern Nigeria
}

\author{
Unanaonwi Okpo Esio ${ }^{1 *}$ and Ake Iyidamiebhon Bertha ${ }^{2}$ \\ ${ }^{I}$ Department of Biology, Federal University Otuoke, Bayelsa State, Nigeria \\ ${ }^{2}$ Department of Microbiology, Federal University Otuoke, Bayelsa State, Nigeria \\ *Corresponding author
}

\begin{abstract}
Soil health is a vital factor in forest productions that cannot be overlooked if forest goods and services must be supplied sustainably. Forest health of a tropical moist rain forest in Federal University Otuoke was investigated using soil physico -chemical properties. Purposeful and sample within block sampling was used. The site was purposely demarcated into three units of $100 \mathrm{~m} \times 100 \mathrm{~m}$ each of virgin forest, secondary forest and agricultural field. Each unit was further divided into $20 \mathrm{~m} \times 20 \mathrm{~m}$ each from which three sample plots per unit was randomly chosen for study. Soil cores were collected using a soil auger from a depth of $0-30 \mathrm{~cm}$ from the three sample sites, and labeled according to forest type. Samples from each forest type were mixed for homogeneity and $1 \mathrm{~kg}$ of each were sieved to remove stones, sealed in polythene bags and taken to the laboratory for analyses. Chemical analyses were carried out for Acidity, Electrical Conductivity, Soil Organic Carbon, Total Nitrogen, Phosphorus, and Potassium. Data were analyzed using ANOVA with a follow up Post Hoc Test. Results shows that out of the seven soil parameters investigated, Electrical conductivity has a mean value $(423 \mu \mathrm{S} / \mathrm{cm})$, while Soil Organic Carbon has a mean value $(4.1 \%)$. The secondary forest has the highest mean value of the physico-chemical properties (90) while the Agricultural field has the least (69). Forest stands did not significantly affect soil parameters $(\mathrm{P}=0.05)$. Physico-chemical properties were highly significant $(\mathrm{P}$ $=0.0001)$. Post Hoc Test shows that variations among physico-chemical properties were as a result of the variation in the means of individual pairs. Forest stands do not affect soil physico - chemical properties in the study area.
\end{abstract}

\begin{abstract}
Article Info
Accepted: 30 July 2017

Available Online: 20 August 2017
\end{abstract}

\section{Keywords}

Soil health,

Tropical Moist Rain Forest,

Forest type,

Physico-Chemical Properties,

Forest Good and Services.

\section{Introduction}

Soil health encompasses availability and usability of soil nutrients, high productivity in terms of crop yield and timber volume, as well as retentively and sustainability of soil nutrients after production or harvest. Filion et al., (1999) stated that a healthy soil is one, which contains either an adequate supply of plant nutrients in an available form, or a microbial population, which releases nutrients fast enough to maintain rapid plant growth. Soil health is the result of continuous conservation and degradation processes and represents the continued capacity of soil to function as a living system (Karlen $e t$ al., 2012). It is simply defined as the capacity of the soil to function. Important soil functions include: water flow and retention, solute transport and retention, physical 
stability and support; retention and cycling of nutrients; buffering and filtering of potentially toxic materials; and maintenance of biodiversity and habitat (Karlen et. al., 2012).

There is a growing concern on the demand for food and shelter for the world growing population. The old concept of large scale agriculture and forestry by using chemical fertilizers to boost agricultural and forest productions to meet this demand has over the years proved unsuccessful as this has led to soil toxicity, environmental pollution and loss of vegetation (Unanaonwi and Amonum, 2014). The current global emphasis is on sustainable forestry and agriculture, but with no concerted efforts towards actions that would ensure the soil remains healthy. Toxic waste dumping, deforestations, and bush burning still persist among rural people. Agriculture and forestry practices should be predicated on sound evaluation of the health of a soil. The hope of feeding the world by 2025 may not be realized if greater attention is not paid to addressing the need to ensure the soil in every environment remains healthy by encouraging every action that tends to promote healthy soil.

Human wellbeing depend on the benefits provided by nature, such as food, fibers, timber, construction materials, clean water, clean air and climate regulation. The forest ecosystem from where majority of these benefits comes depend on the soil, and soil biodiversity is the driving force behind their regulation (Torsvik, et al., 2002; Killham, 1994; Altieri, 1999).

Soil bacteria play a major role in conserving or enhancing soil quality because so many soil processes flow through these organisms. Soil bacterial communities are dynamic and rapidly adapt to environmental changes, including those caused by soil management (Kennedy et al., 2004). The soil bacterial community, and the biodiversity of that community, has been identified as being important to soil quality, biodiversity and agroecosystem sustainability in general (Brussard et al., 2007).

A soil's bacterial community (along with its physical and chemical soil characteristics) plays a major role in the health and quality of that soil (Doran and Zeiss, 2000; Kennedy and Papendick, 1995). Among the most important of these processes is the decomposition of plant residues and other organic detritus (Kennedy and Papendick, 1995). Incorporated within this process is the formation of soil organic matter (SOM) and cycling of organic forms of nitrogen $(\mathrm{N})$, phosphorous $(\mathrm{P})$, and sulphur (S). Soil organic matter plays a key role in soil quality (Weil and Magdoff, 2004) and availability of nutrients is critical to plant health. Beyond decomposition, bacteria are important in other soil processes. Some soil bacteria fix nitrogen, a critical, often limiting, plant nutrient. Others promote plant growth and health through modulation of plant hormones, providing protection against phytopathogens, or enhancing tolerance to abiotic stresses such as drought and excess salt (Yang, et al., Kloepper, et al., 1999; 2009; Glick, 1995)

Soil bacteria also play a key role in building and stabilizing good soil structure, which in turn affects many soil functions associated with soil quality (Oades, 1993; Tisdall, 1991). The importance of these soil processes and the bacteria roles in them cannot be understated. Price (1988) asserted that without microbial facilitation of soil processes, life as we know it would not exist.

\section{Soil health and Determinants}

The concerns on the sustainability of agricultural systems have increased recently because the world population is ever increasing and so is the demand for food. Feeding seven billion people with environmental sustainability is a challenge for the next generations. Sustainable forestry and agriculture aims at meeting the needs of the present without compromising the productive potential for the next generations. Sustainable yields can only be reached with the maintenance or recovery of soil health. Thus, a healthy soil has been defined as the continued capacity of soil to function as a vital living system, within ecosystem and land-use boundaries, to sustain biological productivity, promote the quality of air and water environments, and maintain plant, animal and human health (Doran and Safley, 1997). To assess the sustainability of a production system, changes in chemical, physical, and biological properties, and the effects on the soil's capacity to support plant growth and exert environmental functions, should be monitored (Doran and Safley, 1997).

Sustainable ecosystems, natural or agricultural, rely on the flux of nutrients across trophic levels, which are mainly intermediated by soil microorganisms (Chen et al., 2003). The soil microbial community is considered critical in any ecosystem, by acting on the decomposition 
of soil organic matter, nutrient cycling, and affecting the soil chemical and physical properties, with direct effects on soil fertility and sustainability.

Soil health definition cannot be generalized for all kinds of soil and soil-use as criticized by Sojka and Upchurch (1999). Thus, indicators of soil health must be selected according to soil use and management, soil characteristics and environmental circumstances. Because of the water logged nature of the soil, rural people believe that the soil in Otuoke is poor and may not be productive for any agricultural or forest practice. Therefore, it is important to investigate the soil health of Otuoke using the general and most used chemical indicators.

\section{Chemical Indicators}

Chemical attributes of soil health are correlated with the capacity to provide nutrients for plants and/or retaining chemical elements or compounds harmful to the environment and plant growth. Soil $\mathrm{pH}$, cation exchange capacity (CEC), organic matter and nutrient levels are the main chemical attributes used in soil health assessment, especially when considering the soil capacity for supporting high yield crops (Kelly et al., 2009). Chemical attributes have been correlated with plant yields and thus the variations of a particular indicator are easily interpreted, and allow a quick improvement of the soil chemical properties by liming and/or fertilization. These soil chemical indicators can also be useful in considering the soil's capacity for sustaining forest production and sustainability, maintaining nutrient cycling, plant biomass and organic matter (Schoenholtz et al., 2000).

Idowu et al., (2008) selected a set of parameters to characterize the soil health among 39 physical, chemical and biological attributes and correlated them with plant growth and yield, in soils under different tillage, rotation and cover cropping. These authors concluded that the most important chemical parameters to be assessed were $\mathrm{pH}$, available $\mathrm{P}, \mathrm{K}, \mathrm{Cu}, \mathrm{Fe}, \mathrm{Mn}$, and $\mathrm{Zn}$.

Soil organic carbon is also a key attribute in assessing soil health, generally correlating positively with crop yield (Bennett et al., 2010). The soil organic carbon affects important functional processes in soil like the storage of nutrients, mainly $\mathrm{N}$, water holding capacity, and stability of aggregates (Silva and Sá-Mendonça, 2007). In addition, the soil organic carbon also affects microbial activity. Hence, this is a key component of soil fertility, especially in tropical conditions, which interacts with chemical, physical, and biological soil properties and must be considered in assessments of soil health.

Objectives of the study: The major objective of the study is investigate soil health status under three different forest stands in the study area

Hypothesis: Different forest stands have no significant effects on soil health in the study area.

\section{Materials and Methods}

\section{Place of Investigation}

The Federal University, Otuoke (FUO), in Ogbia Local Government Area (LGA) of Bayelsa State, Nigeria, is one of nine new federal universities established by the Federal Government of Nigeria in February 2011. The university is located in the Niger Delta region of Nigeria.

The campus is being developed on a 2,000,000 square meters (200 hectares) site, on land donated by the indigenes of Otuoke Community in Bayelsa State. The site is geographically located at Latitude ${\mathrm{N} 04^{0}}^{\circ} 47^{\prime} 32.7^{\prime \prime}$, and Longitude $\mathrm{E} 006^{\circ} 19^{\prime} 31.4$ ' ' and is situated in the heart of the community along the Otuoke - Emeyal Road. The entire land had been a virgin forest, a buffer secondary forest and a farming area before it was donated.

The university lies in the low land high rainfall belt of Nigeria. The climate is tropical monsoon characterized by short dry season from November to March, and rainy season from April to October. A short period of dry spell is usual in August. The relative humidity is usually above $80 \%$ in the rainy season, and may decrease to below $50 \%$ in the dry season. Harmattan occurs usually in December and January characterized by low relative humidity and dusty winds.

\section{Demarcation of Sampling Plots}

The study site was purposely demarcated into three units of $100 \mathrm{~m} \times 100 \mathrm{~m}$ each of virgin forest, secondary forest and agricultural field. Each unit was further sub- divided into $20 \mathrm{~m} \times 20 \mathrm{~m}$ each from which three sample plots per unit was randomly chosen for the study. Three soil cores were collected using a soil auger from a depth of $0-30 \mathrm{~cm}$ from the three sample plots (virgin, secondary and 
agricultural field). A total of nine soil samples were collected and labeled according to land use type. Samples from each forest type were mixed for homogeneity and $1 \mathrm{~kg}$ of each were sieved to remove stones, sealed in polythene bags and taken to the laboratory for analyses.

\section{Laboratory Analyses}

\section{Soil pH determination}

The $\mathrm{pH}$ meters were first standardized with $\mathrm{pH}$ buffer 4 , 7 and 9. Reading was taken from 1:1 solution of soil sample to water after leaving sample for proper mixing within an hour period.

\section{Electrical Conductivity (E/C)}

The conductivity of the soil samples was determined by method of electrometric method using handheld battery operated meters. The meter was first standardized with potassium chloride salt before taking the reading on the test samples.

\section{Total Organic Carbon (TOC) and Total Organic Matter (TOM)}

The total organic carbon was determined by Rapid Titration Method (Walkey-Black Method, 1934). A representative sample of soil was weighed into $250 \mathrm{ml}$ conical flask; the weight taken was dependent on the soil characteristic (anticipated organic content usually determined from the soil color). $10 \mathrm{ml}$ of $1 \mathrm{~N}$ potassium Dichromate and $20 \mathrm{ml}$ conc. $\mathrm{H}_{2} \mathrm{SO}_{4}$ was added and vigorously mixed for $1 \mathrm{~min}$. after which the content of the flask was allowed to stand on asbestos for 30min. $100 \mathrm{ml}$ of distilled water was added afterwards, 3 to 4 drops of ferroin indicator was added after which the mixture was titrated with ferrous sulfate solution from a greenish cast to a maroon red end point. The result obtained is the representative of organic carbon in the soil expressed as \% TOC as follows-

$\% \mathrm{C}=\mathrm{B}-\mathrm{T} \times 0.3 \times \mathrm{V} \times 100 / \mathrm{W} \times \mathrm{B} \times 75$

Where,

$\mathrm{B}=$ Blank titre,

$\mathrm{T}=$ Sample titre,

$\mathrm{W}=$ Weight of soil and

$\mathrm{V}=$ Volume of potassium Dichromate

\section{Soil Potassium Test}

The soil mineral nitrogen test was determined using the LaMotte garden soil test kit model EM, Code 5934. The test tube was filled to line 7 with Potassium Extracting Solution. A $0.5 \mathrm{~g}$ spoon was used to add four measures of soil sample to test tube, capped and shake vigorously for one minute. The cap was removed and the soil was allowed to settle. A clean pipet (dropper with the red bulb) was used to transfer the clear liquid to another clean test tube.

A second test tube was filled to line 5 with the liquid. One potassium indicator tablet was added to the soil extract in the second tube, capped and shaken to dissolve the tablet. A purplish color appears. A potassium test solution was added two drops at a time. A running count of the drops used was kept. The test tube was swirled after each addition to mix the contents. When the color changes from purplish to blue, addition of the drops was stopped and the total number of drops added was recorded. The potassium end point color chart was used as a guide in reading the color change.

\section{Soil Mineral Nitrogen (SMN)}

The standard procedure for the analysis of available soil nitrogen as described in MAFF Reference Book 427, 'The Analysis of Agricultural Materials' (Anon., 1986) was used. In the procedure, 2 Molar potassium chloride $(\mathrm{KCl})$ was used for extraction. The extract was then filtered and analysed for nitrate $\mathrm{N}$ and ammonium $\mathrm{N}$ by colorimetric method. The bulk density of the soil was used for the conversion of the nitrate and ammonium $\mathrm{N}$ concentrations to quantities per hectare.

\section{Soil Phosphorus (P) Test}

This was determined using the Morgan soil test method whereby the soil is shaken (extracted) with a chemical solution (sodium acetate buffered at $\mathrm{pH} 4.8$ ) to extraction solution ratio (1:5) for 15 minutes.

The extract was filtered and the $\mathrm{P}$ concentration in the filtered extract was measured colorimetrically.

\section{Soil Temperature}

The temperature of the soil was determined by dipping the thermometer directly in the sample sites and the readings were taking along the caliberated lines on the thermometer. 


\section{Data Analyses}

The data generated were analyzed using Analysis of Variance (ANOVA) for completely randomized design. All statistical analyses were carried out using Microsoft Excel (2008).

\section{Results and Discussion}

From the table above, site B has the highest mean value of soil physico-chemical properties among the three forest stands investigated, while the agricultural field has the least.

The ANOVA table above tells us that the effect of forest stands (sites A, B and C) is not significant with P-value of 0.124 , but the effect of soil physico-chemical parameters is highly significant with probability value of 0.0001 at $5 \%$ level. A Post Hoc Tests was carried out to ascertain the exact pairs of physico- chemical properties that produced the observed differences.

The table shows that it is the means difference among various pairs of physico-chemical properties that actually brought about the total variation.

The physico-chemical parameters of soil investigated in this study were Electrical conductivity EC, Temperature, Soil Acidity, Soil Organic Carbon, Nitrogen, Potassium and Phosphorus. These parameters and nutrient levels have been reported to be the main chemical attributes used in soil health assessment (Kelly et al., 2009). Table.1 shows that Electrical conductivity EC, has the highest mean value of $423.333(\mu \mathrm{S} / \mathrm{cm}) / \mathrm{g}$. The next mean value is Potassium $(70.000 \mathrm{ppm}) / \mathrm{g}$. Soil organic carbon has the lowest mean value of $4.100 \% / g$ in the soil of the study area. Soil in the study area is classified as Andisols. Andisols has a peculiar characteristic of high salinity which is responsible for the high electrical conductivity observed in this study.

High EC therefore implies high salinity in soil which cause imbalance in ions and nutrient uptake, and when the soil is salty, soil water potential will be decreased and plants roots will not be able to absorb enough water, which has implications on nutrient uptake and growth especially in forest trees (www.researchgate.net 2017). This situation does not support our earlier definition of a healthy soil which included availability and usability of soil nutrients, since available nutrients must be dissolve in water for plant uptake.

Soil organic carbon has the lowest mean value of $4.100 \%$. This result for SOC is not unexpected in the sense that salinity or high EC, as recorded in this study, cause ion imbalance and nutrient deficiency which could decrease plant productivity (Setia et al., 2012). It means that increase in electrical conductivity or soil salinity will bring decrease in soil organic carbon. This physicochemical property does not support a healthy soil because organic soil has SOC range of $12-18 \%$ in a wetland or moist soil.

Table.1 Mean values of physico-chemical properties of a tropical moist rain forest soil in Federal University Otuoke

\begin{tabular}{lll}
\hline Physico-chemical properties & Mean & Std. Error \\
E/C $(\mu \mathrm{S} / \mathrm{cm})$ & 423.33 & 11.31 \\
Temperature $\left({ }^{\circ} \mathrm{C}\right)$ & 24.33 & 9.12 \\
$\mathrm{pH}$ & 7.90 & 6.42 \\
TOC $(\%)$ & 4.10 & 4.8 \\
Nitrogen $(\mathrm{ppm})$ & 17.00 & 8.0 \\
Potassium $(\mathrm{ppm})$ & 70.00 & 6.4 \\
Phosphorus $(\mathrm{ppm})$ & 31.33 & 5.2 \\
\hline
\end{tabular}

Table.2 Mean values of physico-chemical properties of a tropical moist rain forest soil from three different forest stands in Federal University Otuoke

\begin{tabular}{lllll}
\hline Forest stands & Mean & Std. Error & Lower Bound & Upper Bound \\
Virgin (A) & 88.529 & 7.402 & 72.400 & 104.657 \\
Secondary (B) & 90.100 & 7.402 & 106.228 & 48.969 \\
Agricultural field (C) & 69.086 & 7.402 & 52.958 & 85.21 \\
\hline
\end{tabular}


Table.3 Two-way ANOVA showing the effect of forest stands on physico-chemical properties of a tropical moist rain forest soil in Federal University Otuoke

\begin{tabular}{llllll}
\hline Sources of variation & $\begin{array}{l}\text { Type III Sum } \\
\text { of Squares }\end{array}$ & df & Mean Square & F & Sig. \\
\hline Corrected Model & $416899.023^{\mathrm{a}}$ & 8 & 52112.378 & 135.867 & .000 \\
Intercept & 143178.857 & 1 & 143178.857 & 373.296 & .002 \\
2 location & 1918.220 & 2 & 959.110 & 2.501 & $.124^{\text {ns }}$ \\
Physico-chem. & 414980.803 & 6 & 69163.467 & 180.323 & $.001^{* *}$ \\
Error & 4602.640 & 12 & 383.553 & & \\
Total & 564680.520 & 21 & & & \\
Corrected total & 421501.663 & 20 & & & \\
\hline
\end{tabular}

Table.4 Multiple Comparisons of means of soil Pysico-chemical properties

\begin{tabular}{|c|c|c|c|c|c|}
\hline $\begin{array}{l}\text { (i)Physico- } \\
\text { Chemical }\end{array}$ & $\begin{array}{l}\text { (j)Physico- } \\
\text { Chemical }\end{array}$ & Mean (i-j) & Sig. & Lower Bound & Upper Bound \\
\hline \multicolumn{6}{|l|}{ Tukey HSD } \\
\hline $\mathrm{E} / \mathrm{C}(\mu \mathrm{S} / \mathrm{cm})$ & $\begin{array}{l}\text { Temperature } \\
\text { pH } \\
\text { SOC }(\%) \\
\text { Nitrogen }(\mathrm{ppm}) \\
\text { Potassium }(\mathrm{ppm}) \\
\text { Posphorus(ppm) }\end{array}$ & $\begin{array}{l}399.00000^{*} \\
415.43333^{*} \\
419.23333^{*} \\
406.33333^{*} \\
53.33333^{*} \\
392.00000^{*}\end{array}$ & $\begin{array}{l}.000 \\
.000 \\
.000 \\
.000 \\
.000 \\
.000\end{array}$ & $\begin{array}{l}338.8299 \\
355.2632 \\
359.0632 \\
346.1632 \\
293.1632 \\
331.8299\end{array}$ & $\begin{array}{l}459.1701 \\
475.6030 \\
479.4035 \\
466.5035 \\
413.5035 \\
452.1701\end{array}$ \\
\hline Tempareture & $\mathrm{E} / \mathrm{C}(\mu \mathrm{S} / \mathrm{cm})$ & $-399.0000 *$ & .000 & -459.1701 & -338.8299 \\
\hline $\mathrm{pH}$ & $\begin{array}{l}\mathrm{E} / \mathrm{C}(\mu \mathrm{S} / \mathrm{cm}) \\
\text { Potassium(ppm) }\end{array}$ & $\begin{array}{l}-415.4333 * \\
62.1000^{*}\end{array}$ & $\begin{array}{l}0.000 \\
.041\end{array}$ & $\begin{array}{l}-475.6035 \\
-122.2701\end{array}$ & $\begin{array}{l}-355.2632 \\
-1.9299\end{array}$ \\
\hline $\operatorname{SOC}(\%)$ & $\begin{array}{l}\mathrm{E} / \mathrm{C}(\mu \mathrm{S} / \mathrm{cm}) \\
\text { Potassium(ppm) }\end{array}$ & $\begin{array}{l}-415.4333^{*} \\
65.9000 *\end{array}$ & $\begin{array}{l}.000 \\
.028\end{array}$ & $\begin{array}{l}-479.4035 \\
-126.0701\end{array}$ & $\begin{array}{l}-359.0632 \\
-5.7299\end{array}$ \\
\hline Nitrogen(ppm) & $\mathrm{E} / \mathrm{C}(\mu \mathrm{S} / \mathrm{cm})$ & $-406.3333^{*}$ & .000 & -466.5035 & -346.1632 \\
\hline Potassium(ppm) & $\begin{array}{l}E / \mathrm{C}(\mu \mathrm{S} / \mathrm{cm}) \\
\mathrm{pH} \\
\mathrm{SOC}(\%)\end{array}$ & $\begin{array}{l}-353.3333^{*} \\
62.1000 * \\
65.9000^{*}\end{array}$ & $\begin{array}{l}.000 \\
.041 \\
.028\end{array}$ & $\begin{array}{l}-413.5035 \\
1.9299 \\
5.7299\end{array}$ & $\begin{array}{l}-293.1632 \\
122.2701 \\
126.0701\end{array}$ \\
\hline Phosphorus & $\mathrm{E} / \mathrm{C}(\mu \mathrm{S} / \mathrm{cm}$ & $-392.0000 *$ & .356 & -21.5035 & .8368 \\
\hline
\end{tabular}

The values with asterisk $(*)$ in column show significance differences at $5 \%$ level of significance.

Forest type and site conditions are biotic factors that impact on the chemical properties of the soil that supports it. There is a continuous interaction between tree and soil. The level and form of interactions depends on the forest type, tree composition and the species above ground.

For all seven soil chemical properties investigated in the study, the secondary forest (A) has the highest mean value (90.100 Table 2.), followed by the virgin forest
(88.529), while the least is the agricultural field with 69.086 .

The virgin forest (site A) is in the inward part of the study area away from many public contacts such as extraction, burning and farming, while the secondary forest (site B) is more of a buffer area to the virgin forest. Much presence of public contacts could be observed in the secondary forest. Here, burning of trees to extract wood-fuel is in continuum. When forest trees are burnt, 
ash and carbon is deposited on the forest floor which eventually gets into the soil, making it alkaline, thus increasing salinity of the soil impacting on electrical conductivity and potassium levels. The high mean values of these parameters in soils from the Secondary forest could be attributed to this phenomenon. However, bush burning also goes on before planting in the agricultural field, yet we observed the lowest mean value of soil chemical properties.

Burning in the agricultural field is lighter than what is obtained in the secondary forest which is composed of forest trees with heavy litter, while the agricultural field is just shrubs therefore, the spent ash or carbon is very thin on the agricultural field.

Another explanation for the observed train is that since the land or soil is in use for cropping and on annual basis, these parameters, otherwise, soil nutrients are being removed on continual basis thereby making the agricultural field low in the investigated soil pysicochemical properties as revealed in this study.

Table. 3 reveals that effect of forest stands were not significantly different, meaning that variation in physico chemical properties did not depend on forest stands with probability value of 0.124 . However, variations in physico-chemical properties were highly significant with $\mathrm{P}$ - value of 0.0001 at $5 \%$ level of significant.

The variations observed in soil parameters were not as a result location or forest type but within the parameters themselves even if examined from a particular forest stands. The Post Hoc multiple comparisons (Table. 4) show that the observed variations in the physico chemical properties arose as a result of conglomeration of means of different pairs of these parameters.

Soil health of the study area was investigated on the back drop that we cannot talk about forest productivity in terms of supplies of goods and services in a sustainable manner without giving adequate attention to the health status of the forest soil.

This would be a bench mark for ascertaining whether a soil can sustain production in a sustainable manner. It was discovered from the study that forest type does not affect soil physico-chemical properties and these properties varies within themselves in a forest type. Soil health should be measured in relation to the type of crop it would sustain and its nutrients requirement, whether in forestry or in agricultural productions.

\section{References}

Altieri, M.A., (1999). The ecological role of biodiversity in agroecosystems. Agriculture, Ecosystems and Environment, 74, 19-31.

Cantarella, H., (2007). Nitrogenio = Nitrogen. p. 375470. In: Novais, R.F., Alvarez, V., Barros, N.F., Fontes, R.L.F., Cantarutti, R.B., Neves, J.C.L., eds. Fertilidade do solo = Soil fertility.Sociedade Brasileira de Ciencia do Solo, Vicosa, MG, Brazil. (In Portuguese).

Chen, G., Zhu, H., Zhang, Y. (2003). Soil activities and carbon and nitrogen fixation. Research in Microbiology, 154, 393-398.

Doran, J.W., Safley, M. (1997). Defining and assessing soil health and sustainable productivity. p. 1-28. In: Pankhurst, C.E., Doube, B.M., Gupta, V.V.S.R., eds. Biological indicators of soil health. CAB International, Wallingford, UK.

Doran, J.W., Zeiss, M.R. (2000). Soil health and sustainability: managing the biotic component of soil quality. Applied Soil Ecology 15, 3-11. doi:10.1016/s0929-1393(00)00067-6.

Filion, M., St-Arnaud, M. and Fortin, J.A., (1999). Direct interaction between the arbuscula mycorrhizal fungus Glomus intraradices and different rhizosphere microorganisms. New Phytology 141, 525-533.

Glick B.R., (1995). The enhancement of plant growth by free living bacteria. Canadian Journal of Microbiology, 41 (Suppl 2), 109-114.

Idowu, O.J., van Es, H.M., Abawi, G.S., Wolfe, D.W., Ball, J.I., Gugino, B.K., Moebius, B.N., Schindelbeck, R.R., Bilgili, A.V. (2008). Farmeroriented assessment of soil quality using field, laboratory, and VNIR spectroscopy methods. Plant Soil 307, 243-253.

Karlen, D.L. (2012). Soil health: The concept, its role, and strategies for monitoring. In Soil Ecology and Ecosystem Services; Wall, D.H., Bardgett, R.D., Behan-Pelletier, V., Herrick, J.E., Jones, H., Ritz, K., Six, J., Strong, D.R., van der Putten, W.M., Eds., Oxford University Press: New York, NY, USA, (2012). pp. 331-336.

Kelly, B., Allan, C., Wilson, B.P., (2009). Soil indicators and their use by farmers in the Billabong Catchment, southern New South Wales. Australian Journal of Soil Research 47, 234-242.

Kennedy, A.C., Papendick, R.I. (1995). Microbial characteristics of soil quality. Journal of Soil and Water Conservation 50, 243-248. 
Kennedy, A.C., Stubbs, T.L., Schillinger, W.F. (2004). Soil and crop management effects on soil microbiology. In: Magdoff, F., Weil, R.R. (Eds.) Soil organic matter in sustainable agriculture. CRC Press. Boca Raton, FL. pp. 295-326.

Killham, K., (1994). "Soil Ecology." Cambridge University Press, Cambridge, UK.

Kloepper, J.W., Rodriguez-Kabana, R., Zehnder, G.W., Murphy, J.F., Sikora E., Fernandez, C. (1999). ASDS Keynote Address Session 3. Plant rootbacterial interactions in biological control of soilborne diseases and potential extension to systemic and foliar diseases. Australasian Plant Pathology 28, 21-26. doi:10.

Oades, J.M., 1993. The role of biology in the formation, stabilization, and degradation of soil structure. Geoderma 56, 377-400. doi:10.1016/00167061(93)90123-3.

Pankhurst, C.E., Magarey, R.C., Stirling, G.R., Blair, B.L., Bell, M.J., Garside, A.L. 2003. Management practices to improve soil health and reduce the effects of detrimental soil biota associated with yield decline of sugarcane in Queensland, Australia. Soil and Tillage Research 72, 125-137.

Price, P.W., 1988. An overview of organismal interactions in ecosystems in evolutionary and ecological time. Agriculture, Ecosystems and Environment 24, 369-377.

Silva, I.R., SA Mendonca, E. 2007. Materia organica do solo $=$ Soil organic matter. p. 275-374. In: Novais, R.F., Alvarez, V.H., Barros, N.F., Fontes, R.L.F.,
Cantarutti, R.B., Neves, J.C., eds. Fertilidade do solo $=$ Soil fertility. Sociedade Brasileira de Ciencia do Solo, Viosa, MG, Brazil (in Portuguese).

Sojka, R.E., Upchurch, D.R. (1999). Reservations regarding the soil quality concept. Soil Science Society of America Journal 63, 1039-1054.

Torsvik, V., Ovreas, L., Thingstad, T.F. (2002). Prokaryotic diversity - Magnitude, dynamics, and controlling factors. Science 296, 1064-1066.

Unanaonwi O.E., and Amonum, J.I. 2014. Changes in tropical forest vegetation composition: The long term impacts, International Journal of Development and Sustainability, Vol. 3 No. 3, pp. 456-465. Online ISSN: 2168-6662. www.isdsnet.com/ijds www.researchgate.net 2017. How does soil salinity affects soil health? Retrieved $18^{\text {th }}, 2017$.

Weil, R.R., Magdoff. F. (2004). Significance of soil organic matter to soil quality and health. In: F.Magdoff, F., Weil, R.R. (Eds.) Soil organic matter in sustainable agriculture. CRC Press CRC Press, Boca Raton, FL. pp. 1-43.

Yang, J., Kloepper, J.W., Ryu, C. 2009. Rhizosphere bacteria help plants tolerate abiotic stress. Trends in Plant Science 14, 1-4. doi:10.1016/j.tplants.2008.10.004.

Zhang, P., Li, L., Pan, G., Ren, J. 2006a. Soil quality changes in land degradation as indicated by soil chemical, biochemical and microbiological properties in a karst area of southwest Guizhou, China. Environmental Geology 51, 609-619.

\section{How to cite this article:}

Unanaonwi Okpo Esio and Ake Iyidamiebhon Bertha. 2017. Evaluation of Soil Health under Different Forest Stands in a Tropical Moist Rain Forest of Otuoke, Southern Nigeria. Int.J.Curr.Res.Aca.Rev. 5(8), 67-74. doi: https://doi.org/10.20546/ijcrar.2017.508.010 